Case Report

\title{
Analysis and Reference of the Profit Structure of MTR
}

\author{
Hong Zhang ${ }^{1,2}$, Mei Hou ${ }^{1,2}$ \\ ${ }^{1}$ Shenzhen Metro Group Co., LTD., Shenzhen, China \\ ${ }^{2}$ Shenzhen Institute of Soft Science, Shenzhen, China
}

Email address:

zhh096@126.com (Hong Zhang),yffhm@163.com (Mei Hou)

\section{To cite this article:}

Hong Zhang, Mei Hou. Analysis and Reference of the Profit Structure of MTR. European Business \& Management. Vol. 4, No. 3, 2018, pp. 92-100. doi: 10.11648/j.ebm.20180403.15

Received: June 21, 2018; Accepted: August 17, 2018; Published: October 8, 2018

\begin{abstract}
As the backbone of urban public transport, metro has a great promoting effect on the development of social economy. However, most metro companies suffer losses in the world. With the expansion of business scope, the diversification of business types and increased profit channels, MTR has become one of the models of the global railway operation industry. To refer to MTR's management experience, and explore its key business to realize profit and its practical lessons, it's necessary to analyze the profit structure of MTR from 2012 to 2014. According to characteristic of MTR business, the profit structure is reconstructed as three major business sectors: passenger transport and its related business, property and its related business, and other business, and the profit structure from 2012 to 2014 is analyzed from total profit constitution and profit source structure. The results show that MTR's profit source structure is highly consistent with its business model "Railway + Property", its passenger transport and property all have strong profitability and each accounting for half of the total profit. For the metro enterprises in mainland China, it should adhere to the development pattern of "Metro + Property" and give full play to the linkage effect of metro and property development, so as to achieve self-sustainable development. It should not only manage well passenger transport and its related businesses, but also manage well property and its related businesses. At the same time, it is also of great significance to explore the flexible fare adjustment mechanism, control and reduce the cost of passenger transport and innovate the valuation model of investment property, etc.
\end{abstract}

Keywords: MTR, Profit Structure, Passenger Transport, Property Development

\section{Introduction}

As the backbone of urban public transport, metro has a great promoting effect on the development of social economy. Since its inception, MTR Corporation ("MTR") has won the recognition from government and citizens with scientific management way, advanced management idea and good service attitude. The business scope gradually expands, the business type gradually diversifies, and the profit channel gradually increases. Through the analysis of the profit structure of MTR from 2012 to 2014, the author aims to explore the key business to realize profit and its practical lessons, so as to provide a reference for the development of metro in mainland China.

\section{Review of Related Literature}

Since 2000, with the rapid development of urban rail transit, scholars and business people have begun to study how the metro companies to achieve profitability.

Some scholars believe that how to obtain returns of positive externalities has become the core of profitability for the metro companies. Government subsidies and authorization of property development rights to metro companies are two feasible modes to solve positive externalities [1]. "Metro operation + benefit return" profit model was proposed, where the former represents operation on metro lines and ancillary resources, the latter includes return of value-added benefit from real estate properties along the metro line [2]. An integrated profit model for rail transit and land development is introduced to promote the urban rail transit to step into a sound development path [3].

Some scholars study the metro companies' profit model from the perspective of cost and benefit. Unbalanced relationship between cost and benefit restricts the 
development of urban rail transit, and it's supposed to gradually improve rail transit profit model through the integrated development and market-oriented operation of rail transit and land development [4]. "Increasing revenue and reducing expenditure" was proposed to realize metro profit, wherein, "increasing revenue" is mainly reflected in ticket revenue, resource development revenue, land development revenue and financial subsidies; "reducing expenditure" is mainly represented by cost control and incorporation of scientific financing plans and management modes [5]. The rail transit resources are abundant and the passenger flow is huge, metro companies could create a variety of profitable businesses, such as advertising and commerce, branding and chain operations [6].

More scholars have explored why MTR is profitable and delivered reviews on how to use MTR profit model. The content of "rail + property" was analyzed from components of the profit model, namely profit growth point, profit object, profit measures and profit barrier [7]. The profitability of MTR mainly benefit from its market-oriented operating mechanism, investment and financing system, ticket pricing model and property development along metro lines [8-9]. MTR continues to expand its business areas related to metro operation based on capital and resource compensation, which has involved passenger service, property development and leasing, station business, advertising, project management, consultancy, etc. And the above is the key of MTR to maintain high profitability for many years [10-12].

MTR has undoubtedly become a leader in the rail transit industry with its profitability. It is of great significance to analyze its profit structure. The analysis is conducted from 5 aspects: MTR business overview, general analysis of profit structure, analysis of profit structure reconstruction, profit constitution of main profit source and business and the referential significance to the metro in mainland China.

\section{Overview of MTR Business}

Since Hong Kong opened its first metro line in 1979, MTR's business scope, scale of operation and geographical coverage have developed with a steady pace and been increasingly diverse, and MTR has become one of the models of the global railway operation industry. In addition to traditional passenger transport business, MTR also expands its business field to station business, including leasing of retail shops at the station, advertisements at the train and station and telecommunication services, etc. Meanwhile in order to take full advantage of the passenger flow resources brought by metro operation, MTR also works with the property developers to develop the residence-based property available for sale as well as holding investment property based on shopping malls and office buildings, and provides property management services for the above and other properties.

In addition, MTR also operates cable car business, Octopus Card payment system, consulting services and project management service, etc. In recent years, in order to seek new opportunities for railway and railway-related business development, MTR has begun to expand its business portfolio related to railways in mainland China and abroad, not only investing in the construction and operation of urban railway and related property development projects located in mainland China (such as Line 14 of Beijing metro, Line 4 of Shenzhen metro, Shenzhen property development "Tiara" project, etc.), also obtaining the exclusive right to operate international railways in UK, Sweden and Australia.

From 2012 to 2014, the performance of four major businesses (passenger transport business, station business, property and other businesses, business in mainland China and international business) grew steadily, the operating income of each business increased continuously, and the profit space gradually expanded.

\section{General Analysis of MTR's Profit Structure from 2012 to 2014}

MTR's profit source and overall structure [13-15] from 2012 to 2014 are shown in Table 1. As seen from Table 1, the characteristics of MTR's profit structure from 2012 to 2014 are as follows:

1) MTR's operating profit source business includes 5 sectors: passenger transport business in Hong Kong, station business in Hong Kong, property rental and management business in Hong Kong, business in mainland China and international subsidiaries and other business;

2) In addition to the current operations, property development and investment property revaluation are also its important profit sources. Their profit proportion accounted for about $45 \%$ of the total profit in 2012 and 2014. In 2013, due to policy impact ("Regulations on the Sale of First-Hand Residential Properties" entered into force at the end of April 2013, the sale of new residential projects slowed down, so the sale of first-hand residence fell to a new record low [15]), property development slowed down, property development profit fell sharply, and their total profit proportion was about $39 \%$ in 2013 ;

Table 1. Analysis of Profit Source and Structure of MTR from 2012 to 2014.

\begin{tabular}{|c|c|c|c|c|c|c|}
\hline & 2012 & & 2013 & & 2014 & \\
\hline Item & $\begin{array}{l}\text { Amount of } \\
\text { Money /HK } \\
\text { \$ million }\end{array}$ & $\begin{array}{l}\text { Proportion } \\
(\%)\end{array}$ & $\begin{array}{l}\text { Amount of } \\
\text { Money /HK } \\
\text { \$ million }\end{array}$ & $\begin{array}{l}\text { Proportion } \\
(\%)\end{array}$ & $\begin{array}{l}\text { Amount of } \\
\text { Money /HK } \\
\text { \$ million }\end{array}$ & $\begin{array}{l}\text { Proportion } \\
\text { (\%) }\end{array}$ \\
\hline Income & 35739 & 100.00 & 38707 & 100.00 & 40156 & 100.00 \\
\hline Including: revenue from passenger transport business & 14523 & 40.64 & 15166 & 39.18 & 16223 & 40.40 \\
\hline Revenue from station business & 3680 & 10.30 & 4588 & 11.85 & 4963 & 12.36 \\
\hline Revenue from property leasing and management & 3401 & 9.52 & 3778 & 9.76 & 4190 & 10.43 \\
\hline
\end{tabular}




\begin{tabular}{|c|c|c|c|c|c|c|}
\hline & 2012 & & 2013 & & 2014 & \\
\hline Item & $\begin{array}{l}\text { Amount of } \\
\text { Money /HK } \\
\text { \$ million }\end{array}$ & $\begin{array}{l}\text { Proportion } \\
(\%)\end{array}$ & $\begin{array}{l}\text { Amount of } \\
\text { Money /HK } \\
\text { \$ million }\end{array}$ & $\begin{array}{l}\text { Proportion } \\
(\%)\end{array}$ & $\begin{array}{l}\text { Amount of } \\
\text { Money /HK } \\
\text { \$ million }\end{array}$ & $\begin{array}{l}\text { Proportion } \\
(\%)\end{array}$ \\
\hline \multicolumn{7}{|l|}{ business in Hong Kong } \\
\hline Revenue from mainland and international subsidiaries & 12786 & 35.78 & 13246 & 34.22 & 12627 & 31.44 \\
\hline Other business incomes & 1349 & 3.77 & 1929 & 4.98 & 2153 & 5.36 \\
\hline Cost & \multicolumn{2}{|l|}{ (22 656)100.00 } & \multicolumn{2}{|l|}{ (24 308)100.00 } & $(24733)$ & 100.00 \\
\hline Including: expenses from passenger transport business & $(7829)$ & 34.56 & $(8449)$ & 34.76 & (9 236) & 37.34 \\
\hline Expenses from station business & $(397)$ & 1.75 & $(464)$ & 1.91 & $(515)$ & 2.08 \\
\hline $\begin{array}{l}\text { Expenses from property leasing and management } \\
\text { business in Hong Kong }\end{array}$ & (627) & 2.77 & (673) & 2.77 & (747) & 3.02 \\
\hline Expenses from mainland and international subsidiaries & $(12$ 184) & 53.78 & $(12455)$ & 51.24 & $(11821)$ & 47.79 \\
\hline Expenses from other businesses & $\left(\begin{array}{ll}1 & 619\end{array}\right)$ & 7.15 & $(2$ 267) & 9.33 & $(2414)$ & 9.76 \\
\hline $\begin{array}{l}\text { Operating profit (excluding the profit from property } \\
\text { development, depreciation, amortization and } \\
\text { non-quota payment each year) }\end{array}$ & 13083 & - & 14399 & - & 15423 & - \\
\hline Profit from property development & 3238 & - & 1396 & - & 4216 & - \\
\hline Depreciation \& amortization & (3 208) & - & (3 372) & - & $(3485)$ & - \\
\hline Non-quota payment per year & $(883)$ & - & (1 247) & - & $(1472)$ & - \\
\hline Interest and financial expenses & $(879)$ & - & $(732)$ & - & $(545)$ & - \\
\hline Investment property revaluation & 3757 & - & 4425 & - & 4035 & - \\
\hline Profit or loss attributed to associated company & 456 & - & 158 & - & 121 & - \\
\hline Total profit & 15564 & - & 15027 & - & 18293 & - \\
\hline Income tax & $\left(\begin{array}{ll}1 & 893\end{array}\right)$ & - & $\left(\begin{array}{ll}1 & 819\end{array}\right)$ & - & $(2$ 496) & - \\
\hline Net profit & 13671 & - & 13208 & - & 15797 & - \\
\hline
\end{tabular}

3) Seen from the report structure of MTR, its depreciation and amortization, interests and financial expenses are not included in operating costs, but are solved in the profit from property development and investment property revaluation after the operating profit, which is consistent with the previous ideas to deal with asset depreciation and financing interest [16].

\section{Analysis of MTR's Profitability Structure Reconstruction from 2012 to 2014}

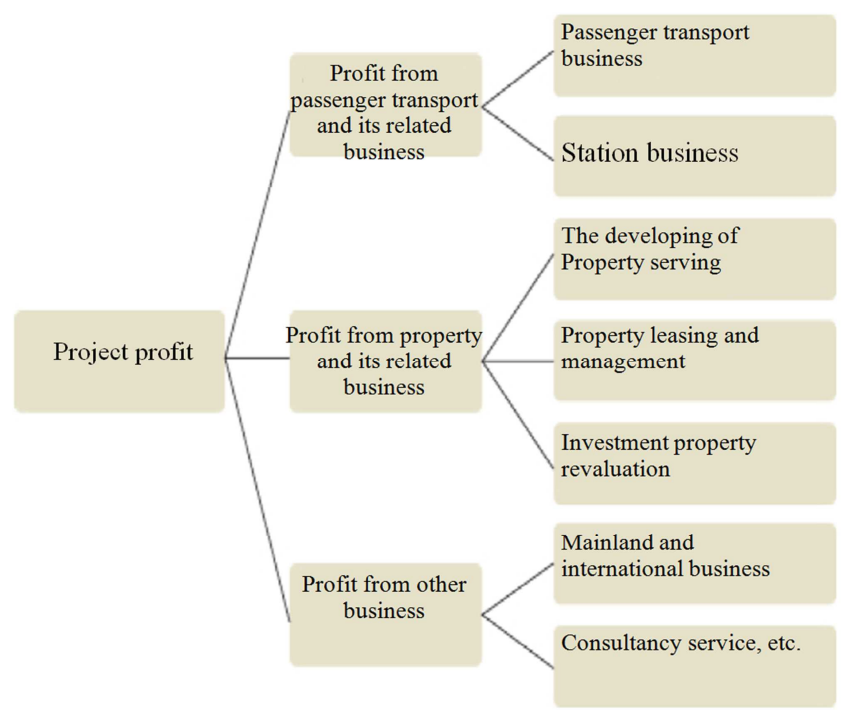

Figure 1. Profit Structure Reconstruction of MTR.

To more directly reflect and analyze the main profit sources of MTR, according to the characteristics of the service constitution of MTR, the author adjusted MTR's list of consolidated profit and loss items of annual report for the year 2012 to 2014 and reconstructed its profit structure. The reconstructed profit structure of MTR is shown in Figure 1.

After reconstruction, the main profit source can be divided into three major sectors: profit from passenger transport and its related business, profit from property and its related business and profit from other businesses. Of which, the profit from passenger transport and its related business comes from passenger transport business and station business, the profit from property and its related business comes from property development, property leasing and management, and investment property revaluation, and the profit from other businesses is mainly from the business in mainland China and international business and consulting services, etc.

As seen from the data in Table 1, MTR's total profit in the consolidated profit and loss statement from 2012 to 2014 was HK \$15.564 billion, HK \$15.027 billion, and HK \$18.293 billion respectively. The items of interest and financial expense differ from those of the metro enterprises in mainland China, which has less impact on MTR's overall profit and loss due to its more abundant capital and lower borrowing costs; the proportion of annual non-quota payment and the profit or loss attributable to associated companies is small in the total profit, and the majority of the metro enterprises in mainland China do not have such two types of business or have a small business volume. When reconstructing items of profit, the author eliminated three profit and loss items: annual non-quota payment, profit or loss attributable to associated companies, interest and financial expenses. After reconstruction, MTR's total profit amounted to HK $\$ 16.870$ billion, HK $\$ 16.848$ billion, and HK \$20.189 billion respectively from 2012 to 2014 . The corresponding depreciation has been deducted in the calculation of profit from passenger transport business, station business, property leasing and 
management and other businesses; considering that service concession asset and the business of metro enterprises in mainland China have no general character, all of its amortization is included in other businesses; meanwhile, due to the different tax system, the income tax expense cannot be compared, so it is not included in the analysis scope in this analysis. Composition of specific profit items [13-15] is shown in Table 2.
As seen from Table 2, MTR's profit from 2012 to 2014 mainly comes from passenger transport and its related business, property and its related business (the profit from other businesses is negative). The following focuses on the analysis of profit constitution of passenger transport and its related business and property and its related business.

Table 2.Constitution of Reconstructed Profit Amount of MTR from 2012 to 2014.

\begin{tabular}{|c|c|c|c|c|c|c|c|c|}
\hline \multirow[b]{2}{*}{ Reward structure } & \multicolumn{2}{|l|}{2012} & \multicolumn{3}{|l|}{2013} & \multicolumn{3}{|l|}{2014} \\
\hline & $\begin{array}{l}\text { Amount of } \\
\text { Money } \\
\text { /HK } \\
\text { \$ million } \\
\end{array}$ & $\begin{array}{l}\text { Proportion } \\
(\%)\end{array}$ & $\begin{array}{l}\text { Amount of } \\
\text { Money } \\
\text { /HK } \\
\text { \$ million } \\
\end{array}$ & $\begin{array}{l}\text { Proportion } \\
(\%)\end{array}$ & $\begin{array}{l}\text { Increase } \\
\text { rate }\end{array}$ & $\begin{array}{l}\text { Amount of } \\
\text { Money } \\
\text { /HK } \\
\text { \$ million } \\
\end{array}$ & $\begin{array}{l}\text { Proportion } \\
(\%)\end{array}$ & $\begin{array}{l}\text { Increase } \\
\text { rate }\end{array}$ \\
\hline $\begin{array}{l}\text { Profit from passenger transport and its } \\
\text { related business }\end{array}$ & 7401 & 100.00 & 8178 & 100.00 & 10.50 & 8712 & 100.00 & 6.53 \\
\hline Passenger transport business & 4236 & 57.24 & 4167 & 50.95 & -1.63 & 4371 & 50.17 & 4. 90 \\
\hline $\begin{array}{l}\text { Profit from property and its related } \\
\text { business }\end{array}$ & 9761 & 100.00 & 8916 & 100.00 & -8.66 & 11682 & 100.00 & 31.02 \\
\hline The developing of Property serving & 3238 & 33.17 & 1396 & 15.66 & -56.89 & 4216 & 36.09 & 202. 01 \\
\hline Investment property revaluation & 3757 & 38.49 & 4425 & 49.63 & 17.78 & 4035 & 34.54 & -8.81 \\
\hline Property leasing and management & 2766 & 28.34 & 3095 & 34. 71 & 11.89 & 3431 & 29.37 & 10.86 \\
\hline profit from other operations & -292 & 100.00 & -246 & 100.00 & -15.75 & -205 & 100.00 & -16.67 \\
\hline Mainland and international business & 535 & -183.22 & 719 & -292.28 & 34.39 & 740 & -360.98 & 2.92 \\
\hline
\end{tabular}

\section{The Profit Constitution of Two Major Business Sectors}

\subsection{Proportion of Profit Sources}

The two major sectors: passenger transport and its related business, property and its related business. Profit and its proportion in total profit [13-15] are shown in Table 3.

Table 3.Profit from two major business sectors and its proportion in total profit.

\begin{tabular}{|c|c|c|c|c|c|c|}
\hline \multirow[b]{2}{*}{ Item } & \multicolumn{2}{|l|}{2012} & \multicolumn{2}{|l|}{2013} & \multicolumn{2}{|l|}{2014} \\
\hline & $\begin{array}{l}\text { Amount of } \\
\text { Money /HK } \\
\text { \$ million } \\
\end{array}$ & $\begin{array}{l}\text { Proportion } \\
(\%)\end{array}$ & $\begin{array}{l}\text { Amount of } \\
\text { Money /HK } \\
\text { \$ million }\end{array}$ & $\begin{array}{l}\text { Proportion } \\
(\%)\end{array}$ & $\begin{array}{l}\text { Amount of } \\
\text { Money /HK } \\
\text { \$ million }\end{array}$ & $\begin{array}{l}\text { Proportion } \\
(\%)\end{array}$ \\
\hline Profit from passenger transport and its related business & 7401 & 43.12 & 8178 & 47.84 & 8712 & 42.72 \\
\hline Passenger transport business & 4236 & 24. 68 & 4167 & 24. 38 & 4371 & 21.43 \\
\hline Station business & 3165 & 18.44 & 4011 & 23. 46 & 4341 & 21.29 \\
\hline Profit from property and its related business & 9761 & 56.88 & 8916 & 52. 16 & 11682 & 57.28 \\
\hline Investment property revaluation & 3757 & 21.89 & 4425 & 25.89 & 4035 & 19. 79 \\
\hline Property leasing and management & 2766 & 16. 12 & 3095 & 18. 11 & 3431 & 16. 82 \\
\hline Total & 17162 & 100.00 & 17094 & 100.00 & 20394 & 100.00 \\
\hline
\end{tabular}

The proportion of sources for profit from two major business sectors of MTR from 2012 to 2014 is shown in Figure 2.

As seen from Figure 2, the proportion of sources for profit from two major business sectors of MTR from 2012 to 2014 is very and relatively stable. In addition to the ratio slight fine-tuning in 2013, the remaining two years of profit from passenger transport and its related business accounted for approximately $43 \%$, and the profit from property and its related business accounted for approximately 57\%. While passenger transport and its related businesses gained operating profits, property and its related businesses undoubtedly provided strong support for MTR's profit. The structure of profit-source of MTR reflects MTR's business model characteristics. As MTR's board of directors stated in its annual report that the "Railway + Property" pattern had brought good benefits to MTR for decades. 


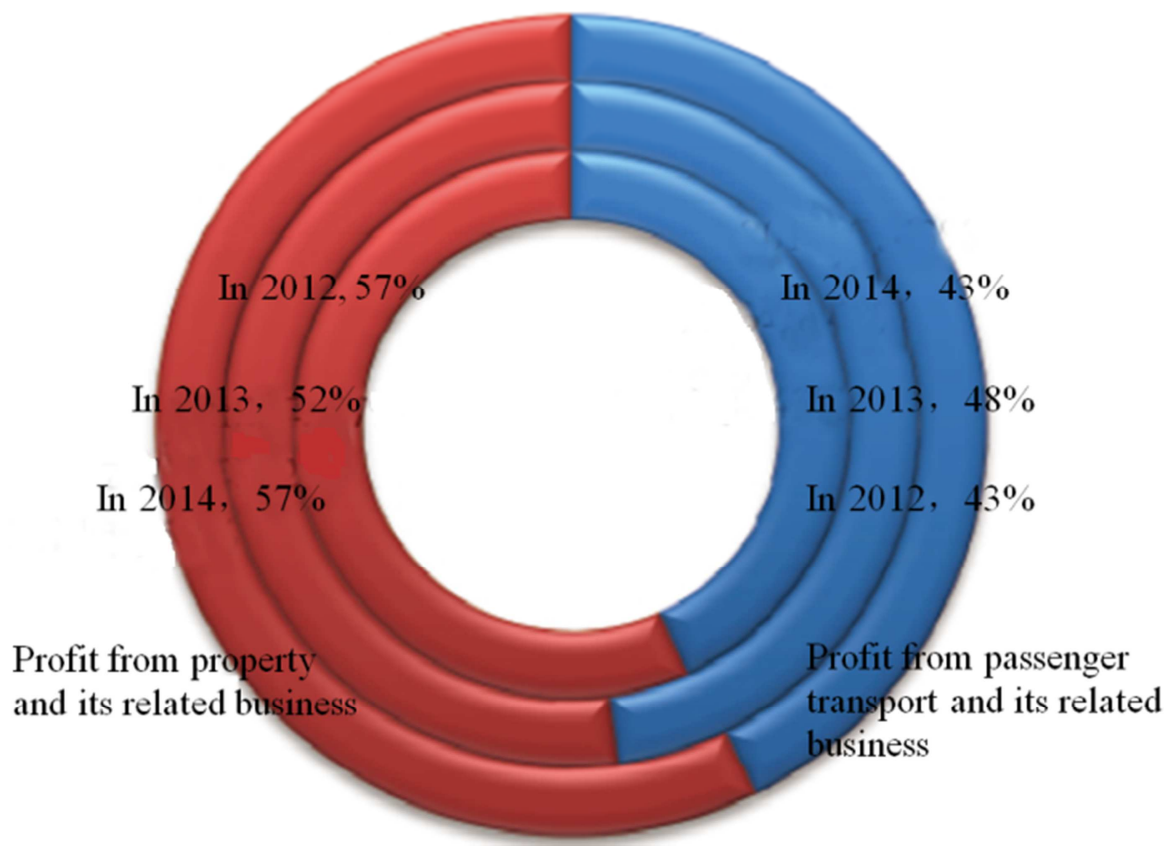

Figure 2. The Proportion of Sources for Profit from Two Major Business Sectors.

\subsection{The Proportion of Five Business Profit Sources}

The proportion of five business profit sources of MTR from 2012 to 2014 is shown in Figure 3.

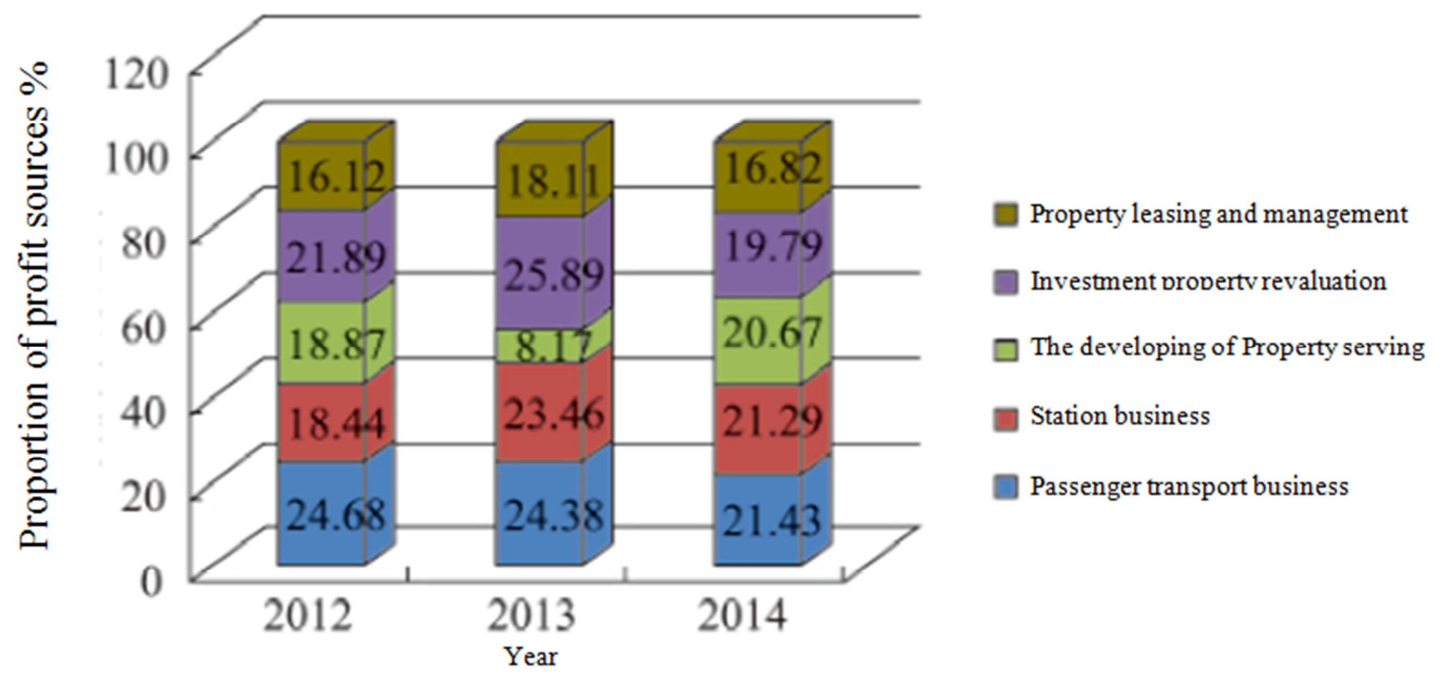

Figure 3.Proportion of Five Business Profit Sources.

As seen from Figure 3, the proportion of five business profit sources of MTR is basically balanced, about $20 \%$. The proportion of a business in the profit structure of a certain year is mainly influenced by economic climate and market factors. According to MTR's annual report, the growth rate of property development of MTR slowed down in 2013, and the proportion of profit from property development was significantly lower than that for the other two years, which was mainly affected by the policy. Entry-into-force of Regulations on the Sale of First-Hand Residential Property made the slow down the sales pace of new residential projects, making the sales volume of first-hand residential property fall to a record low. In addition, the government's measures to stabilize the property price and prevent speculation also had a certain impact on the development of the property [14].

\subsection{Analysis on the Constitution of Profit from Passenger Transport and Its Related Business}

The proportion of sources for profits on MTR's passenger transport and its related business from 2012 to 2014 is shown in Figure 4. 


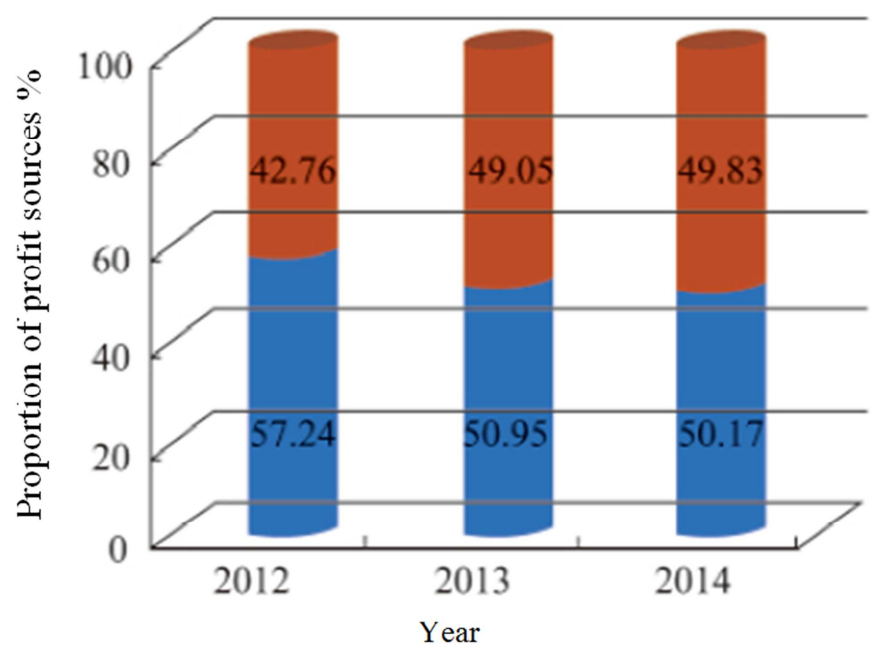

Station business

Passenger transport business

Figure 4. The Proportion of Sources for Profit from MTR's Passenger Transport and Its Related Business.

Passenger transport and station business are the basic business of MTR. Of which, passenger transport business mainly includes local railway service, border-crossing service, airport express, light railway, bus and inter-city passenger transport service; the station business includes duty-free store, small shop, advertising, telecommunications and so on. According to horizontal comparison (see Figure 4), the profit ratio of passenger transport and station business is roughly half and half, but the profit from station business is increasing year by year, and the amount of profit from station business and passenger transport business in 2014 is quite close; according to vertical comparison (see Table 2), based on the average annual growth rate from 2012 to 2014 , the profit increase of station business is greater compared with the increase in profit from passenger transport business. MTR's passenger transport business index [13-15] is shown in Table 4.

Table 4. MTR's Passenger Transport Business Index.

\begin{tabular}{llll}
\hline Year & $\mathbf{2 0 1 2}$ & $\mathbf{2 0 1 3}$ & $\mathbf{2 0 1 4}$ \\
\hline Total line length / km & 218 & 218 \\
Total number of passengers/ 10,000 persons & 177064 & 221 \\
Daily passenger capacity /10,000 persons & 484 & 182340 \\
Income from per passenger/Hong Kong dollar & 8.2 & 500 & 8.31 \\
Operating expenses for per passenger/ Hong Kong dollar & 4.18 & 522 & 4.27 \\
Earned profit from per passenger/Hong Kong dollar & 4.02 & 8.52 & 4.47 \\
\hline
\end{tabular}

In the aspect of passenger transport business, it is clear from Table 4 that MTR's income from each passenger is HK \$8.2, HK $\$ 8.31$ and HK $\$ 8.52$ respectively from 2012 to 2014 , and the earned profit from each passenger excluding depreciation and amortization is $\mathrm{HK} \$ 4.02$, HK \$4.04 and HK \$4.05 respectively. Apart from a large number of stable passenger flow (in 2014, MTR's daily passenger flow exceeded 5.2 million, MTR's occupation rate of market was more than $48 \%$ in the public transport market in Hong Kong), an important reason for MTR to achieve good metro operation efficiency is a flexible fare adjustment mechanism (MTR's metro fare adjustment equation: adjusted proportion $=0.5 \times$ general price index $+0.5 \times$ index of wage in transport industry-feedback part from productivity improvement). According to MTR's annual report from 2012 to 2014, in addition to adjusting the appropriate journey fare according to the fare adjustment mechanism per year, MTR also reviewed the fare adjustment mechanism every five years, to establish a fair, transparent and acceptable fare adjustment mechanism for all relevant persons, including shareholders and passengers [13]. In April 2013, MTR Corporation and the local government completed the first fare mechanism review every five years. The overall fare mechanism adjustment equation and its direct driving method maintained unchanged, but it introduced an objective and transparent method to calculate the numeric value of productivity factors (based on the new calculation methodology, the productivity factor from 2013 to 2017 was $0.6 \%$, so the fare adjustment range in 2013 was $2.7 \%$ and not $3.2 \%$ ). As a result, passengers enjoyed a lower fare than the original increasing range. In addition, as part of the fare review mechanism, MTR Corporation also provided passengers with additional fare concessions, such as "Buy Ten Get One Free", 10 \% Discount for Every Same-day Second Trip and MTR City Saver, etc.

In the aspect of station business, by the end of 2014, the number of MTR shops reached 1350, and the total area of retail facilities was $55,696 \mathrm{~m}^{2}$. In 2014 , retail revenue of the station reached HK $\$ 3.197$ billion (i.e. daily rental reached HK $\$ 157 / \mathrm{m}^{2}$ ), with a gross operating profit rate of $89.6 \%$.

\subsection{Analysis of Profit Constitution of Property and Its Related Business}

The proportion of sources for profit from property and its related business is shown in Figure 5. 


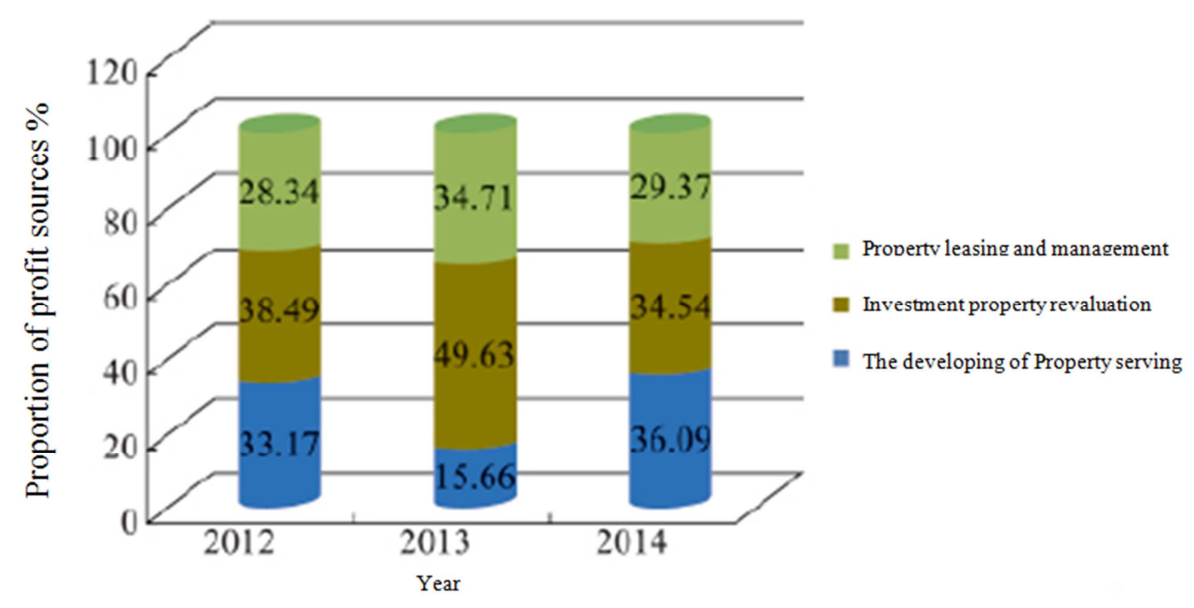

Figure 5. Proportion of Sources for Profit from Property and Its Related Business.

Property and its related business (including property development, investment property revaluation, property leasing and management) contributed more than half of the profits of MTR. According to horizontal comparison (see Figure 5), the profit ratio of three major business in the profit from property and its related business was about $1 / 3$ (due to market fluctuations in 2013, the investment property revaluation significantly exceeded the profit from property development). Among them, the appreciation of investment property was an important profit source of MTR, accounting for about $20 \%$ of MTR's comprehensive profit (see Table 3), which mainly benefited from the developed real estate market and the sustained and stable economic development in Hong Kong; according to vertical comparison(see Table 2), based on average annual growth rate from 2012 to 2014, the biggest increase in profit was from the development of property, followed by property leasing and management.

Successful implementation of the "Railway + Property" model was the key to MTR's continued high profits. According to this model, MTR developed a large number of property, office buildings, shopping centers, high-end residences along the railway in Hong Kong. Although the profit from property development of individual year fluctuated due to market impact (with the combination of MTR and Kowloon-Canton Railway, MTR's profit from property development exceeded HK \$3 billion in 2012 and in 2014, except in 2013), MTR continued to maintain stable profit growth from property development. On the one hand, MTR has real estate properties and space using right, which optimizes the use efficiency of the land by constructing a high-density residential area connected with the railway, and meanwhile, MTR benefits from the economic potential arising from the development of commercial and residential property above and around the station; on the other hand, MTR is mostly in cooperation with regional land agents whose scale and brand strength is very strong, so good brand effect and geographical advantage provide a rich return for MTR.

In the aspect of property leasing and management, by the end of 2014, MTR's properties available for rent included $212,500 \mathrm{~m}^{2}$ of retail properties, $41,000 \mathrm{~m}^{2}$ of office buildings and $14300 \mathrm{~m}^{2}$ of properties for other purpose. The rental income was HK \$ 4.19 billion and the gross operating interest rate was $82.2 \%$, accounting for about $30 \%$ of the property-related profits (see Table 2).

\section{Conclusion and Reference}

\subsection{Conclusion}

Through the analysis of the profit structure of MTR from 2012 to 2014, it is found that the operation of MTR has the following characteristics:

1) MTR's business model is "Railway + Property", and MTR's structure of profit source is in good agreement with its business model. About half of MTR's total profit from 2012 to 2014 comes from passenger transport and its related business, and the other half comes from property and its related business. The two major business sectors have strong profitability.

2) The profit from passenger transport and its related business of MTR mainly comes from two major parts: one is passenger transport business, and the other is station business. In addition to higher fares, the profitability of its passenger transport business is also related to its control of passenger transport cost which accounts for $54 \%$ to $57 \%$ of its passenger transport revenue (see Table 1). In the profit from passenger transport and its related business, the profit from station business is increasing year by year, approaching $50 \%$ of the profit from passenger transport and its related business. In addition to benefiting from the active business climate in Hong Kong, the continued growth of business profits in MTR stations mainly benefits from the synchronous planning and design of subway commerce at the beginning of the line planning, ongoing brand promotion and optimal combination of tenants for the station shops, continual innovation of advertising form and timely sales package to increase its attraction.

3 ) In the constitution of profit from property and its related business, property development, investment property revaluation, property leasing and management contribute about $1 / 3$ respectively. The proportion of profit from property 
leasing and management from 2012 to 2014 was kept basically stable at $30 \%$. In 2013 , due to market factors, the proportion of profit from property development was significantly reduced, and the profit from investment property revaluation, property leasing and management provided a good supplement and support.

\subsection{Use for Reference}

Throughout the excellent performance of MTR, whether passenger transport and its related business, or property and its related business, there are many that the subway coterie in mainland China can refer to and learn from.

1) Insist on the operation mode of "Metro + Property" and give full play to the linkage effect of metro and property development. Focus on the research of the opportunities to develop property along the metro lines. Through huge earnings from land development and property development along the metro lines, the regurgitation-feeding for metro operation and new line construction will be successfully realized, thereby the value maximization of the integrated development of metro project and property project will be realized.

2) Explore a flexible fare adjustment mechanism to regularly adjust the fare. When referring to MTR's experience in fare formulation, we should comprehensively consider the factors such as the local price level, average wage in society, labor productivity to set the fare fluctuation mechanism, and adjust the fare annually according to the fare fluctuation mechanism, and also review the fare mechanism on a regular basis. In addition, we can also offer a profit-related concessionary scheme for the fare, such as a monthly ticket plan.

3) Control and reduce the cost of passenger transport so as to reduce the passenger income-cost ratio to a reasonable level. MTR's passenger transport business cost in it is $54 \%-57 \%$. Compared with MTR, the operating cost of metro enterprises in mainland China in its operating income is about $100 \%$, which shows that the metro enterprises in mainland China should strengthen the management and control of passenger transport cost while improving passenger transport income by using the fare adjustment mechanism for reference. According to the cost behavior of metro operation, the standard management and control should be carried out for personnel configuration, energy saving and consumption reduction, repairs and maintenance, and management of spare parts with MTR as the benchmark.

4) First metro commerce, and then strengthen and upgrade the brand positioning of the station shops. In the course of commercial planning and design for metro, it is necessary to combine the economic environment and group characteristic in the line planning area, to determine the brand and location of the subway commercial tenants to be introduced, thus providing shopping convenience for passengers. In addition, we should continue to carry out brand publicity and promotion, optimize tenant mix, enhance the attraction of the station shops for the suitable industry, tenants and passengers, to attract the high-quality new brand to enter the subway station and increase the customer's affection and attention to the station shops. For advertisements at the station, it is necessary to continuously innovate the advertisement form and launch activities such as sales packages in order to attract and retain advertisers.

5) Rationally distinguish the sales-type property and the holding-type property, and maintain the sustainability of corporate earnings and cash flow. The residence-based product is defined as sales-type property, with quick sale and quick liquidation to guarantee the cash flow turnover of the property development project; the product based on shopping mall, hotel and office building is defined as holding-type property, with to guarantee continuous cash flow inflow in the subsequent years after the end of the property development project and continuous profit support for management results of enterprises in subsequent years.

6) Innovate the valuation model of investment property, and reduce or stabilize profit volatility caused by revaluation. According to China Accounting Standards, both cost mode and fair value mode can be adopted for follow-up measurement of investment property. If the cost model is adopted, the influence on the is relatively stable, but the real market value of the investment property cannot be objectively reflected in time; if the fair value model is adopted, the performance of the enterprise can fluctuate greatly due to the influence of economic climate and market fluctuation. In order to avoid the of the property value due to the change of the economic situation, the weighted average of cost and fair value can be adopted in the accounting of investment property.

7) Update the structure of profit and loss statement to make the profit and loss calculation of the metro enterprise more consistent with the attributes of the metro industry. With reference to the report structure of profit and loss statement of MTR, depreciation of fixed assets and amortization of intangible assets, interest and financial expenses, profits of property development and revaluation profits of holding-type property will be listed after operating profits and before total profits. In this way, it can objectively reflect the public welfare of depreciation of fixed assets and amortization of intangible assets, interest and financial expenses of metro enterprises and the equilibrium throughout all periods, as well as can reflect the financial necessity and social responsibility for the property development and operation of the metro enterprise.

\section{References}

[1] Miao, Q.H., He, X.Z., \& Fei, F.Y. (2004). Discussion about Externality and Profit Model of Urban Rail Transit. Urban Mass Transit, 05, 9-11.

[2] Zhang, H., Liu, Y., \& Xie, J.G. (2007). Research on Profit Model of Urban Rail Transit based on Sustainable Development. Urban Rapid Rail Transit, 20(05), 9-13.

[3] Xue, L., Yang, Y.T., \& Jiang, D.B. (2011).Discussion about Profit Model of Integration Development of Rail Transit and Land. Urban Rapid Rail Transit, 24(05), 14-17.

[4] Liu, J.L., \& Zeng, X.G. (2004). Discussion about Urban Rail Transit Construction Financing and Profit Development. Urban Mass Transit, 04, 17-21. 
[5] Qin, C.B. (2004). Profit Model Analysis and Research on Relevant Policies of Nanjing Metro Company. Dissertation, Southeast University.

[6] Wang, H. (2005). Research on How to Construct Urban Rail Transit Profit Model. Urban Rapid Rail Transit, 06, 1-4.

[7] Xu, G. (2009). Research on MTR Profit Model. Dissertation, Southwestern University of finance and economics.

[8] Yan, P. (2017). Research on Rail Transit Profit Model. China Journal of Commerce, 23, 10-11.

[9] Shi, J.N. (2011). Analysis of the Positive Externalities for MTR Profit Model. Railway Transport and Economy, 33(06), 81-85.

[10] Cai, W. (2013). Analysis of the Marketization Path of Urban Rail Transit Based on the MTR Mode. Urban Mass Transit, 16(09), 10-13+22.

[11] Wu, Q.N., \& Ye, X.F. (2016). Investigation and Analysis of Typical Urban Rail Transit Operation Revenue at Home and Abroad. Urban Mass Transit, 19(12), 106-110.
[12] Ding, M. (2018). MTR Profit Model and its Enlightenment on Zhengzhou Metro. Contemporary Economics, 05, 66-67.

[13] MTR Corporation Limited. Annual Report for the Year 2012 [EB/ OL]. [2015-06-20]. http: / /www. Mtr. com. Hk /ch /corporate /investor / 2012 frpt. Html

[14] MTR Corporation Limited Annual Report for the Year 2013 [EB/ OL]. [2015-06-20]. http: / /www. Mtr. com. $\mathrm{hk} / \mathrm{ch} /$ corporate/investor /2013frpt. html

[15] MTR Corporation Limited. Annual Report for the Year 2014 [EB/ OL]. [2015-06-20]. http: / /www. Mtr. com. $\mathrm{hk} / \mathrm{ch} /$ corporate/investor /2014frpt. html

[16] Zhang, H., \& Ding, X.H. (2013). Accounting Treatment of Asset Depreciation and Financing Interest in Urban Rail Enterprises Based on Full Life Cycle. Urban Rapid Rail Transit, 26(4), 47-51. 